\title{
DEPLETION OF CARCASS POTASSIUM IN RATS MADE HYPERTENSIVE WITH DESOXYCORTICOSTERONE ACETATE (DCA) AND WITH CORTISONE
}

\author{
By ABBIE I. KNOWLTON AND EMILY N. LOEB \\ (From the Department of Medicine, Columbia University College of Physicians and Surgeons, \\ and the Presbyterian Hospital, New York, N. Y.)
}

(Submitted for publication March 29, 1957; accepted May 13, 1957)

The hypertension which can be induced experimentally in rats by the administration of desoxycorticosterone acetate (DCA) differs from that which develops in rats given cortisone acetate in its dependence upon a liberal sodium intake (1). Not only is DCA-hypertension made more severe by providing the animals with excess sodium (2), but it fails to develop if the available supply of this cation be sufficiently restricted (3). In contradistinction, the capacity of cortisone (1) or of hydrocortisone (4) to elevate the blood pressure is independent of sodium intake.

It seemed of interest, therefore, to determine whether the mechanisms underlying the dissimilar actions of these two groups of steroids would be reflected in the electrolyte composition of the tissues of animals given one or the other compound under conditions of sodium loading as well as of sodium restriction. A preliminary study analyzing pooled samples of tissue indicated that the hypertension induced by DCA was accompanied by an increase in carcass sodium, whereas this did not obtain in the carcasses of rats made hypertensive with cortisone (5).

\section{METHODS}

Sixty young female Sprague-Dawley rats ${ }^{1}$ were divided at random into eight groups, averaging 118 to $135 \mathrm{Gm}$. in body weight. The allocation of the animals and the experimental regimens employed are shown in Table I. The sodium content of the "low $\mathrm{Na}$ " diet on analysis was somewhat higher, and that of the "high $\mathrm{Na"}$ diet somewhat lower, than in the preliminary study. The latter was an intentional modification introduced in the hope of avoiding the high mortality in the DCA-injected group encountered in the preliminary study. $\mathrm{DCA}^{2}$ was administered in sesame oil, subcutaneously, six days

1 Obtained from the Holtzman Co., Madison, Wisconsin.

2 We wish to thank Dr. Kenneth Thompson of Organon, Inc., Nutley, N. J., for generously supplying the desoxycorticosterone acetate. weekly, and cortisone acetate in aqueous suspension ${ }^{8}$ was similarly given. It was necessary to sacrifice the rats of Group VII from four to seven days after the start of the experiment, as they became moribund from adrenal insufficiency. In this brief period all had lost significant amounts of weight, and their blood pressure readings had decreased markedly or were unobtainable.

Blood pressures were measured according to the method of Friedman and Freed (6) but with the modification that the animals were neither immobilized with curare nor anesthetized. Normal values obtained by this modified technique range 10 to $20 \mathrm{~mm}$. $\mathrm{Hg}$ higher than those obtained on anesthetized animals. Readings in Group VII were obtained daily; in other groups readings were made weekly. At sacrifice all animals were anesthetized with Nembutal 8 , then exsanguinated from the incised heart. Blood obtained in this manner from individual rats was separated, and the sera combined with that of two or three other animals to form two pools per group. On these pooled sera, sodium and potassium were determined using a flame photometer with an internal lithium standard; and chloride by the Van Slyke method as modified by Wilson and Ball (7).

After removal of the gastrointestinal canal, heart, kidneys, right gastrocnemius, right femur and a $1-\mathrm{cm}$. square sample of skin, the remaining carcass was frozen.

The individual frozen carcasses were coarsely ground by hand in a small meat grinder, and the water content determined on a $20-\mathrm{Gm}$. aliquot after desiccation for two weeks in an electric oven at $90^{\circ}$ to $105^{\circ} \mathrm{F}$. Fat content was determined on this dried tissue following a 24hour extraction with ethyl ether in a Soxhlet apparatus. The dry defatted tissue was then ground in a mortar and aliquots were taken for sodium, potassium, chloride and nitrogen determinations. For sodium and potassium, 0.4 to $0.5 \mathrm{Gm}$. of tissue were placed in a chloride tube and digested 20 to 30 minutes in a water bath at $80^{\circ}$ to $90^{\circ} \mathrm{C}$. with $5 \mathrm{ml}$. nitric acid, then diluted to approximately 30 ml., filtered twice through washed glass wool and made up to $100 \mathrm{ml}$. volume with 1:200 parts of lithium by weight. Determinations were made in a Baird flame photometer. No corrections for calcium were made, as the amount present in samples of tissue was found insufficient to interfere with the sodium determinations. Similarly, no correction was made for nitric acid, since the small amount of lowering which this substance

\footnotetext{
3 Kindly made available by Merck \& Co., Rahway, N. J.
} 
TABLE I

Allocation of animals

\begin{tabular}{|c|c|c|c|c|c|}
\hline Group & Diet & $\begin{array}{c}\text { Drinking } \\
\text { water }\end{array}$ & Adrenals & Steroid & $\begin{array}{l}\text { Experimental } \\
\text { period }\end{array}$ \\
\hline $\begin{array}{r}\text { I } \\
\text { III } \\
\text { IV } \\
\text { V } \\
\text { VI } \\
\text { VII } \\
\text { VIII }\end{array}$ & $\begin{array}{l}\text { High } \mathrm{Na} \\
\text { High } \mathrm{Na} \\
\text { High } \mathrm{Na} \\
\text { High } \mathrm{Na} \\
\text { Low } \mathrm{Na} \\
\text { Low } \mathrm{Na} \\
\text { Low } \mathrm{Na} \\
\text { Low } \mathrm{Na}\end{array}$ & $\begin{array}{l}0.85 \% \mathrm{NaCl} \\
0.85 \% \mathrm{NaCl} \\
0.85 \% \mathrm{NaCl} \\
0.85 \% \mathrm{NaCl} \\
\text { Tap water } \\
\text { Tap water } \\
\text { Tap water } \\
\text { Tap water }\end{array}$ & $\begin{array}{l}\text { Excised } \\
\text { Excised } \\
\text { Excised } \\
\text { Intact } \\
\text { Excised } \\
\text { Excised } \\
\text { Excised } \\
\text { Intact }\end{array}$ & $\begin{array}{c}\text { mg./day } \\
\text { DCA 2.5 } \\
\text { Cortisone Ac. } 2.5 \\
\text { nil } \\
\text { nil } \\
\text { DCA } 2.5 \\
\text { Cortisone Ac. } 2.5 \\
\text { nil } \\
\text { nil }\end{array}$ & $\begin{array}{c}\text { days } \\
21 \\
21 \\
21 \\
21 \\
21 \\
14 \\
14 \\
4-7 \\
14\end{array}$ \\
\hline
\end{tabular}

* On analysis $\mathrm{Na}$ content $=0.6$ per cent

† On analysis $\mathrm{Na}$ content $=0.1$ per cent.

produces in both the sodium and potassium readings was found to be within the limits of error of the method. For chloride, $0.5-\mathrm{Gm}$. samples were placed in chloride tubes and the same method employed as for sera, with the exception that samples were allowed to stand 24 hours after addition of the silver nitrate and nitric acid before proceeding with heating and titration with ammonium thiocyanate. For nitrogen, a macro-Kjeldahl digestion was carried out on $1-\mathrm{Gm}$. samples. Following digestion and dilution with $130 \mathrm{ml}$. water, the digest was

TABLE II

Comparison of effects of $D C A$ vs. cortisone acetate $(E)$ on body weight, blood pressure and serum electrolytes of adrenalectomized rats

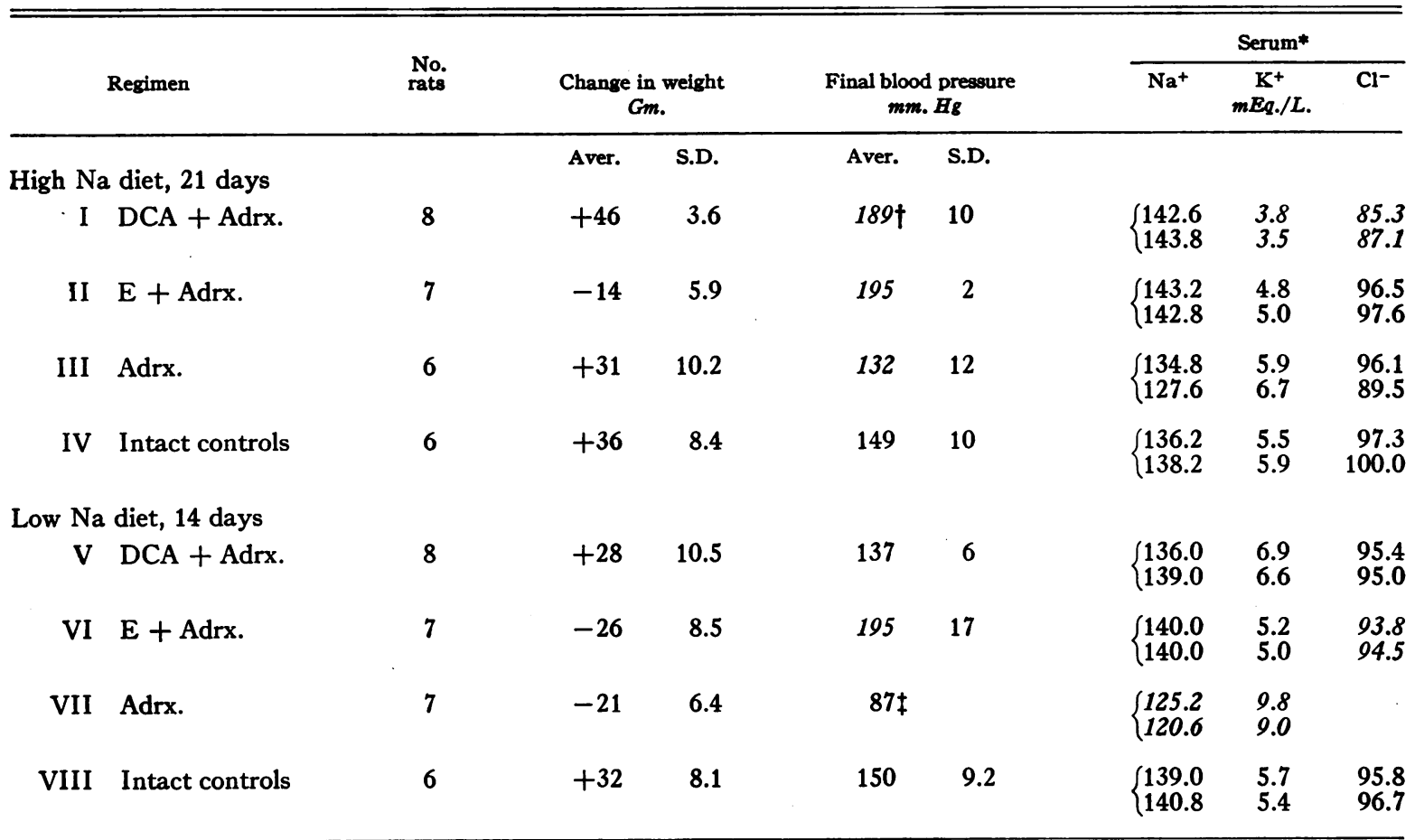

* Each serum value $=$ determination made on pooled sera from 3 to 4 individual rats.

+ Treatment differences in blood pressures were jointly estimated by a 95 per cent simultaneous confidence interval following Tukey (8). (For the individual treatment comparisons this amounts to significance tests more strict than at the 5 per cent level.) Blood pressure values which differed significantly from intact controls on the same regimen have been italicized. For each of the serum electrolytes, treatment differences were based on weighted averages of the pool values and compared again by Tukey's method. Whenever the weighted averages differed significantly from intact controls, the separate determinations were italicized.

$\ddagger$ Rats sacrificed after 4 to 7 days, at which time blood pressure obtainable in only one animal in the group. 
filtered and made to a $250-\mathrm{ml}$. volume. The nitrogen content of a 2-ml. aliquot was then determined after alkalinization by steam distillation of the resulting ammonia, trapped in boric acid and titrated against $\mathrm{N} / 50$ $\mathrm{HCl}$.

\section{RESULTS}

The results are set forth in Tables II and III.

\section{Weight}

In the groups provided with liberal quantities of sodium, essentially normal growth was evidenced by all but the cortisone-injected rats. The impressive weight loss here was consistent with our previous observations (1) and again emphasizes the marked growth-suppressing activity of this steroid in the rat.

Even more striking weight losses were observed in the cortisone-treated group on sodium restriction, whereas the steroid DCA, even under these conditions of limited intake of sodium, permitted normal growth. With no steroid replacement (Group VII) a very severe weight loss was seen even in the brief period of four to seven days during which these animals survived.

\section{Blood pressure}

As anticipated, the hypertensive action of DCA was evident only among those rats receiving liberal amounts of sodium, whereas equally severe degrees of hypertension were seen on the low as well as the high sodium intake among the animals given cortisone.

\section{Electrolytes in sera}

DCA given with liberal quantities of sodium resulted in a significant lowering of the serum potassium and chloride. The serum sodium, when compared to the control group, appeared elevated. When sodium intake was restricted the steroid was a sufficiently potent sodium retainer to maintain a normal serum sodium concentration, but under these conditions no reduction in potassium or chloride occurred. Indeed, the potassium determinations on this regimen were higher than those of control animals.

Unlike DCA, cortisone did not lead to hypochloremia or a reduced serum potassium when given to animals on a high sodium regimen. However, like DCA, cortisone did permit the maintenance of a normal serum sodium concentra-

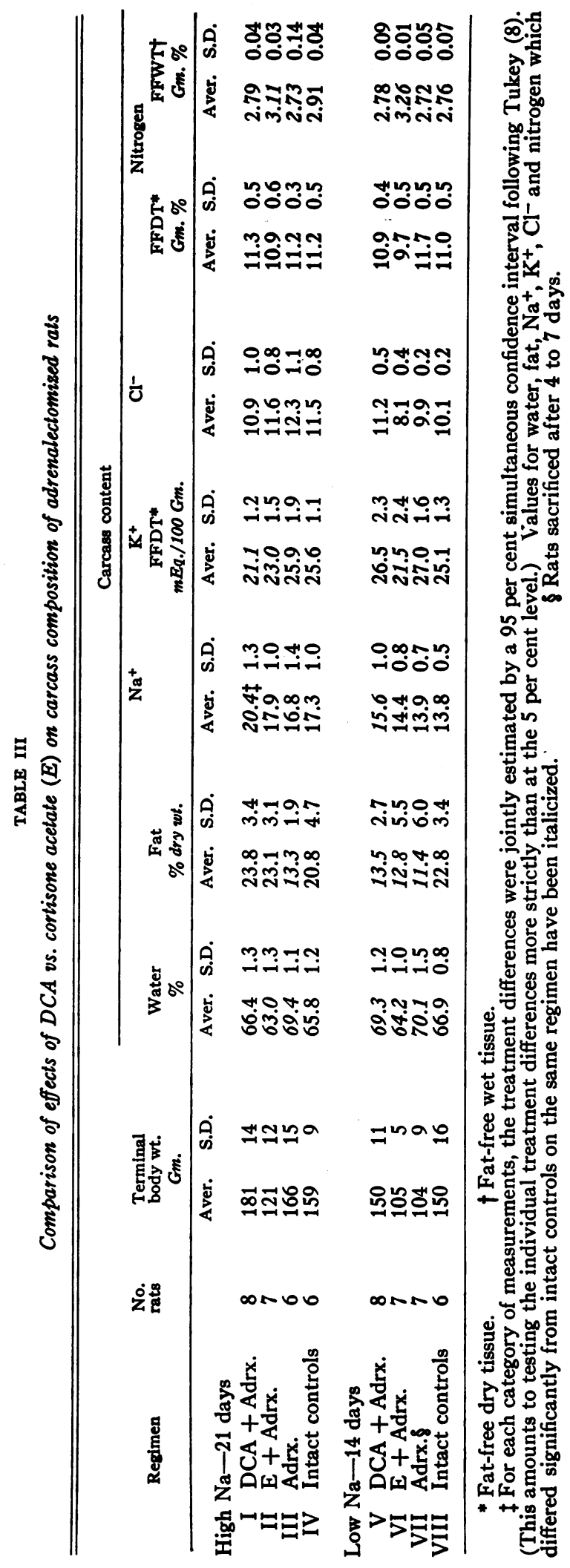


tion even in the face of a restricted intake. On this regimen the serum chloride was lower than normal and the serum potassium appeared lower than in the DCA groups. This latter difference may be a reflection of the different effect of these two steroids in sodium restricted rats upon carcass potassium (see below).

In contrast to both steroid injected groups, the untreated adrenalectomized rats developed striking abnormalities within four to seven days of sodium depletion. In this study, these abnormalities were partially but not completely corrected by the provision of a moderately high sodium intake (see Group III).

\section{Carcass analyses}

$D C A$ groups. The hypertensive DCA rats given liberal quantities of sodium showed an impressive increase in their carcass sodium along with a decrease in potassium. The water content was not significantly greater than that of normal rats and, indeed, was definitely less than that of adrenalectomized rats given no steroid replacement but maintained on a similar high sodium regimen. Since the increase in carcass sodium was not accompanied by an increase in water content or chloride content nor by a decrease in nitrogen, calculated as per cent of fat-free fresh tissue, the increase in sodium in this DCA-injected group is not the result of an extracellular edema; rather, it reflects an intracellular exchange of sodium for potassium. In the DCA-injected animals which remained normotensive on the low sodium regimen, the only electrolyte change as compared to the normal group was a slight increase in carcass sodium, which was accompanied by an increase in water content but not by a reduction in nitrogen as related to wet weight.

Cortisone acetate (E) groups. The striking changes in all hypertensive cortisone injected rats were dehydration and depletion of body potassium. These changes obtained equally in both high and low sodium intake groups. Unlike the hypertensive DCA animals, there was no reciprocal increase in carcass sodium, i.e., the potassium effects here were not secondary to the changes in sodium. In fact, the carcass sodium values in both groups of cortisone-treated rats were not significantly different from those encountered in the intact controls on the respective regimens.
Control adrenalectomized groups. The impressive change observed in these animals on the low as well as those on the high sodium regimen was the increased total body water. It appears that the electrolyte content of the carcasses of the adrenalectomized rats on a high sodium intake was not significantly different from that of normal animals on a similar regimen. On the low sodium regimen a comparison of the adrenalectomized with the intact control group is misleading and probably not justified since the carcasses of the former reflected only four to seven days of sodium restriction, whereas those of the normals were analyzed after a full fourteen days on this regimen.

\section{DISCUSSION}

While the foregoing data point up certain differences in carcass composition between the rats injected with DCA and those which received cortisone acetate, it is clear that all these hypertensive rats exhibited one abnormality in common, i.e., a striking lowering in the total body potassium. This obtained regardless of whether the rise in blood pressure followed DCA or cortisone. Whether this change in potassium is an integral feature in the capacity of adrenal cortical steroids to produce hypertension remains to be determined. Certainly other situations which give rise to potassium deficiency may occur without hypertension.

In the DCA-treated rats a liberal quantity of dietary sodium was necessary for both the rise in blood pressure and the potassium change to become evident. Indeed, the latter change was roughly reciprocal to the increase in carcass sodium. This observed increase in sodium and decrease in potassium is quite in keeping with previously reported changes in skeletal muscle (9-12) of DCA-treated animals, and also compatible with reports of an increase in arterial wall sodium (13) and of a decrease in brain potassium (14). The increase in sodium in the DCA rats of the current experiment is also similar to findings encountered in hypertension due to other causes: 1) an increase in the sodium content of aortae (13), of brain, heart, liver, gut, muscle, skin and spleen (15) and in total carcass (16) in experimental renal hypertension, and 2) an increase in exchangeable sodium (17) and in the sodium content of aortae (18) of humans with severe hypertensive disease. 
However, the increased carcass sodium in the present experiment cannot be considered a reflection of extracellular edema as has been the case in certain instances of renal hypertension $(19,20)$, since these DCA rats did not have an accompanying increase in total body water or chloride, nor did they exhibit a significant decrease in carcass nitrogen expressed as per cent of fat-free wet weight. The increased sodium in this instance is better explained by assuming that an exchange of sodium for potassium has occurred intracellularly.

Although the hypertensive DCA rats all exhibited an increase in carcass sodium, this change cannot be considered essential for the development of a rise in blood pressure per se, since it did not occur in either group of hypertensive cortisoneinjected rats. The non-essential character of the increase in sodium in hypertension has been demonstrated previously by Grollman (21) in rats made hypertensive by ten days of a choline-deficient diet during the third and fourth week of life. In these animals he was unable to find any variation from normal in sodium, potassium, magnesium, chloride or water content of brain, gut, heart, liver, skeletal muscle or skin.

The depletion of carcass potassium observed in the cortisone-injected rats in the current experiment has not, to our knowledge, been reported previously, although it is well recognized that this steroid leads to potassium diuresis in balance studies. Davis, Bass and Overman (12), who observed diuresis of potassium in cortisone- treated dogs, found that tissues from such animals, with intact adrenals, showed potassium depletion in muscle and brain but not in liver, heart, ileum, spleen, lungs or skin. An increase in sodium accompanied the potassium changes in muscle.

The dehydration and the electrolyte changes observed in our studies in the rat cannot be attributed to the marked growth-inhibiting action of the steroid, since no such changes were found in normal rats starved so as to achieve a comparable weight loss (5). This dehydration of the cortisone-treated animals is impressive and may possibly reflect over-activity of the mechanism which regulates water excretion. In contrast there was overhydration in the adrenalectomized rats given no steroid supplement. In the salt depleted group (Group VII) this overhydration was clearly intracellular and is compatible with similar changes reported previously in muscle $(22,23)$. Over-hydration was also evident in the companion group (Group III) afforded a liberal sodium intake, though in this instance, the decrease in the nitrogen values expressed as per cent of fat-free wet weight makes it likely that some portion of the excess fluid was stored extracellularly.

\section{SUMMARY}

The data demonstrate that the carcasses of rats made hypertensive by injection of DCA or of cortisone acetate contain significantly less potassium than normal.

The potassium decrease in the carcasses of rats made hypertensive with DCA is accompanied by a reciprocal increase in carcass sodium. Sodium restriction prevented both the hypertension and, to a large extent, the electrolyte abnormalities.

The potassium decrease in the carcasses of rats made hypertensive with cortisone is not accompanied by a reciprocal change in sodium and develops under conditions of sodium restriction as readily as on a high sodium intake. Whether this correlation between potassium depletion and hypertension has causal significance cannot be stated.

The marked dehydration present in adrenalectomized rats given cortisone and the striking overhydration present in adrenalectomized control rats were equally apparent on high and low sodium intakes.

\section{ACKNOWLEDGMENT}

The authors are indebted to Dr. Agnes Berger and Miss Sheila Smythe, of the School of Public Health and Administrative Medicine of the Faculty of Medicine, Columbia University, for statistical advice in the analysis of the data.

The authors also wish to express their gratitude to Mrs. Josephine Hoban and Mrs. Tania Budzilovich for their expert technical assistance.

\section{REFERENCES}

1. Knowlton, A. I., Loeb, E. N., Stoerk, H. C., White, J. P., and Heffernan, J. F., Induction of arterial hypertension in normal and adrenalectomized rats given cortisone acetate. J. Exper. Med., 1952, 96, 187.

2. Selye, H., Hall, C. E., and Rowley, E. M., Malignant hypertension produced by treatment with desoxycorticosterone acetate and sodium chloride. Canad. M. A. J., 1943, 49, 88. 
3. Knowlton, A. I., Loeb, E. N., Stoerk, H. C., and Seegal, B. C., Desoxycorticosterone acetate, the potentiation of its activity by sodium chloride. J. Exper. Med., 1947, 85, 187.

4. Friedman, S. M., Friedman, C. L., and Nakashima, M., The hypertensive effect of compound F-acetate (17-OH-corticosterone-21-acetate) in the rat. Endocrinology, 1952, 51, 401.

5. Knowlton, A. I., Studies on the hypertensive action of adrenal steroids, In press.

6. Friedman, M., and Freed, S. C., Microphonic manometer for indirect determination of systolic blood pressure in the rat. Proc. Soc. Exper. Biol. \& Med., 1949, 70, 670.

7. Wilson, D. W., and Ball, E. G., A study of the estimation of chloride in blood and serum. J. Biol. Chem., 1928, 79, 221.

8. Tukey, J. W., Comparing individual means in the analysis of variance. Biometrics, 1949, 5, 99.

9. Miller, H. C., and Darrow, D. C., Relation of serum and muscle electrolyte, particularly potassium, to voluntary exercise. Am. J. Physiol., 1941, 132, 801.

10. Ferrebee, J. W., Parker, D., Carnes, W. H., Gerity, M. K., Atchley, D. W., and Loeb, R. F., Certain effects of desoxycorticosterone. The development of "diabetes insipidus" and the replacement of muscle potassium by sodium in normal dogs. Am. J. Physiol., 1941, 135, 230.

11. Darrow, D. C., and Miller, H. C., The production of cardiac lesions by repeated injections of desoxycorticosterone acetate. J. Clin. Invest., 1942, 21, 601.

12. Davis, A. K., Bass, A. C., and Overman, R. R., Comparative effects of cortisone and DCA on ionic balance and fluid volumes of normal and adrenalectomized dogs. Am. J. Physiol., 1951, 166, 493.
13. Tobian, L., Jr., and Binion, J., Artery wall electrolytes in renal and DCA hypertension. J. Clin. Invest., 1954, 33, 1407.

14. Ziegler, M., Anderson, J. A., and McQuarrie, I., Effects of desoxycorticosterone acetate on water and electrolyte content of brain and other tissues. Proc. Soc. Exper. Biol. \& Med., 1944, 56, 242.

15. Laramore, D. C., and Grollman, A., Water and electrolyte content of tissues in normal and hypertensive rats. Am. J. Physiol., 1950, 161, 278.

16. Greene, R. W., and Sapirstein, L. A., Total body sodium, potassium and nitrogen in rats made hypertensive by subtotal nephrectomy. Am. J. Physiol., 1952, 169, 343.

17. Ross, E. J., Total exchangeable sodium in hypertensive patients. Clin. Sc., 1956, 15, 81.

18. Tobian, L., and Binion, J. T., Tissue cations and water in arterial hypertension. Circulation, 1952, 5, 754.

19. Eichelberger, L., The distribution of water and electrolytes between blood and skeletal muscle in experimental hypertension. J. Exper. Med., 1943, 77, 205.

20. Ledingham, J. M., The distribution of water, sodium, and potassium in heart and skeletal muscle in experimental renal hypertension in rats. Clin. Sc., 1953, $12,337$.

21. Grollman, A., The water and electrolyte content of the tissues in hypertension. Circ. Research, 1954, $2,541$.

22. Harrison, H. E., and Darrow, D. C., The distribution of body water and electrolytes in adrenal insuffciency. J. Clin. Invest., 1938, 17, 77.

23. Muntwyler, E., Mellors, R. C., Mautz, F. R., and Mangun, G. H., Electrolyte and water equilibria in the dog. II. Electrolyte and water exchange between skeletal muscle and blood in adrenal insufficiency. J. Biol. Chem., 1940, 134, 367.

\section{SPECIAL NOTICE TO SUBSCRIBERS}

Post Offices will no longer forward the Journal when you move.

Please notify The Journal of Clinical Investigation, Business Office, 333 Cedar Street, New Haven 11, Conn. at once when you have a change of address, and do not omit the zone number if there is one. 